\title{
PERCEPCIJA PROBLEMA, MOGUĆNOSTI I NAVIKA ODVOJENOG PRIKUPLJANJA OTPADA
}

\author{
Sanja Kalambura, Aleksandar Racz, Nives Jovičić i Marko Toth
}

\author{
Veleučilište Velika Gorica \\ Zagrebačka cesta 5, 10410 Velika Gorica \\ e-mail: sanja.kalambura@vvg.hr
}

\begin{abstract}
Sažetak
Cjelovit sustav gospodarenja otpadom temelji se na principu hijerarhijskog koncepta u kojem se na vrhu nalazi izbjegavanje otpada, potom slijedi vrednovanje, a tek na kraju odlaganje. Procjenjuje se kako tek vrlo mali udio od ukupnih količina otpada nastalog u RH tijekom jedne godine nade put $k$ oporabi. Sve se ostalo, mjereno milijunima tona godišnje, odlaže. Prema dosadašnjim referentnim istraživanjima, koja su navedena u radu, problem otpada je percipiran kao značajan.

Istraživanje je imalo za cilj doći do aktualnih saznanja o percepciji odvojenog prikupljanja otpada, a rezultati istraživanja te statistička obrada podataka prikazani su u radu. Rezultati su prikupljeni grupnim anketiranjem. Statističke metode koristene pri obradi podataka su deskriptivna statistika kao i metoda analitičke statistike. U obradi su primijenjene metode univarijatne (postoci) i bivarijatne analize (analiza varijance i t-test). Rezultati su pokazali da više od pola ispitanika od ukupnog uzorka razvrstava otpad u vlastitom kućanstvu, a oni koji ne razvrstavaju kao razlog većinom navode nepostojanje infrastrukture za odvojeno prikupljanje otpada u blizini mjesta stanovanja.
\end{abstract}

Ključne riječi: ekološka svijest, percepcija, otpad, odvojeno prikupljanje otpada, recikliranje

\section{UVOD}

Jedan od ključnih ekoloških problema današnjice je otpad, odnosno njegovo zbrinjavanje. Prema Nacionalnoj Strategiji zaštite okoliša Republike Hrvatske (2002) najveći problem gradova je upravo zbrinjavanje otpada, odnosno neodrživo gospodarenje otpadom.

Također, u velikom broju istraživanja provedenih u posljednjih tridesetak godina, problem neodgovarajućeg zbrinjavanja komunalnog otpada i gomilanje otpada stalno visoko rangira, a rezultati pokazuju i zabrinutost stanovništva za stanje okoliša kada je u pitanju komunalni otpad (Cifrić, 1999, 2005, 2008; Stanić i sur., 2009).

Povećanje količina otpada koji nastaje i njegovo gomilanje rezultat je masovne proizvodnje i potrošnje. Potrošački mentalitet sve je izraženiji, a prekomjerna eksploatacija prirodnih resursa, gomilanje otpadnih tvari i uništavanje prirode i okoliša pridonose poremećaju biološke ravnoteže na Zemlji. Stvaranjem sve većih količina otpada čovjek znatno narušava prirodnu ravnotežu, pa pristup rješavanju problema otpada čini jedan od prioriteta u smanjenju onečišćenja okoliša (Evison i Read, 2001). 
Količina otpada koji nastaje ovisi od razvijenosti pojedine zemlje, pa su tako količine komunalnog otpada razvijenih zemalja daleko veće nego u zemljama u razvoju. Tome u prilog govore i podaci prema kojima su Sjedinjene Američke Države na prvom mjestu po proizvodnji otpada u Svijetu. Njezini stanovnici sudjeluju u svjetskoj populaciji s 3\%, a stvaraju 30\% ukupnog otpada u Svijetu (Hazen, 2005). U Republici Hrvatskoj se, sukladno gospodarskom razvoju i povećanju potrošnje, također bilježi stalni rast proizvedenog komunalnog otpada. U odnosu na prethodne dvije godine, u 2012. godini ukupna količina proizvedenog komunalnog otpada porasla je za 2,5\%. Prema podacima Hrvatske agencije za okoliš i prirodu u 2014. godini ukupno je proizvedeno 1.637.371 t komunalnog otpada. Godišnja količina komunalnog otpada po stanovniku iznosila je $382 \mathrm{~kg}$, odnosno dnevna količina $1,04 \mathrm{~kg}$ proizvedenog komunalnog otpada po stanovniku (AZO, 2015).

Zbrinjavanje otpada ovisi i od pojedinca koji se u svakodnevnom životu može odlučiti između ekološkog ili neekološkog ponašanja, stoga se sve veći naglasak stavlja na individualna ponašanja i prakse kućanstava (Ebreo i Vining, 2001; Van Houtven i Morris, 1995) kao i na strategije koje promoviraju individualna i društvena ponašanja s ciljem recikliranja (Vincente i Reis, 2008), ili na „socijalizaciju protiv otpada“ (De Coverly i sur., 2008). U razvijenim zemljama od 80 -ih godina 20 -og stoljeća do danas provedena su brojna istraživanja o zbrinjavanju i recikliranju otpada te izbjegavanju nastanka otpada. Rezultati su pokazali da kućanstva participiraju u recikliranju prvenstveno zbog uvjerenja da je recikliranje osobna odgovornost svakog pojedinca, a na drugom mjestu su pozitivni stavovi o recikliranju kao jednom od glavnih načina smanjenja onečišćenja i očuvanja resursa (Stanić i sur., 2009; Vincente i Reis, 2008). Rezultati istraživanja uloge socioekonomskog konteksta pojedinca u zbrinjavanju otpada pokazuju različite rezultate, a u ovome istraživanju nije istraživana povezanost socioekonomskih varijabli i razine svijesti o važnosti odvojenog prikupljanja otpada. U jednom od najranijih istraživanja iz 1970. godine (Stanić i sur., 2009) rezultati su pokazali da su ekološki svjesniji mlađi ispitanici, višeg obrazovanja i boljeg ekonomskog statusa, te urbanog podrijetla (Ebreo i Vining, 2001), dok je drugo istraživanje pokazalo da ne postoji jaka povezanost socioekonomskih varijabli i okolišno odgovornog ponašanja (Ebreo i sur., 1999).

U Republici Hrvatskoj provedeno je niz istraživanja koja su se bavila percepcijom onečišćenja okoliša i ugrožavanja prirode u očima mladih (Cifrić i Čulig, 1987), procjenom stanja i očekivanja u odnosu na razvoj i okoliš u Hrvatskoj (Cifrić, 1999), percepcijom ekoloških problema kao zabrinjavajućih (Cifrić, 2005), te zabrinutosti građana ekološkim problemima (Cifrić, 2008). U svim navedenim istraživanjima problem zbrinjavanja i gospodarenja otpadom stalno je istican kao prioritet. Prema Stanić i sur. (2009) odnosno prema istraživanju iz 1998. godine ispitanici su procijenili da će se u slijedećih deset godina, dakle do 2008., povećati problem otpada (Cifrić, 1999), što pokazalo realnom procjenom. U istraživanjima provedenim 1994., 1998. i 2004. godine rezultati su pokazali konstantnu ekološku senzibilnost ispitanika, a u ranijim istraživanjima (iz 1994. i 1998. god.) posebice se izdvaja visoki postotak ispitanika zainteresiranih za zaštitu okoliša (Cifrić, 2008). 
Budući da društvena svijest i osobna motivacija stanovništva, uz postojanje odgovarajuće infrastrukture imaju veliki utjecaj na učinkovitost sustava gospodarenja otpadom provedeno je istraživanje o percepciji problema vezanih uz mogućnost odvojenog prikupljanja otpada i navikama među studentima Veleučilišta Velika Gorica.

\section{CILJ I METODOLOGIJA ISTRAŽIVANJA}

Temeljni cilj istraživanja bio je ispitati percepciju studenata o otpadu odnosno ispitati osobne navike o odvojenom prikupljanju otpada. U okviru posebnih ciljeva istražena je učestalost odvajanja pojedinih kategorija otpada, percepcija o dostupnosti informacija i infrastrukture odvojenom gospodarenju otpadom te navike ispitanika vezane uz odnošenje otpada u reciklažna dvorišta. Također su istraženi najčešći razlozi / motivi za odvojeno prikupljanja otpada kod ispitanika koji otpad odvajaju, odnosno razlozi nerazvrstavanja otpada kod ispitanika koji otpad ne odvajaju na mjestu nastanka te stavovi o potrebi ekološke edukacije i unapređenja infrastrukture.

Istraživanje je provedeno u mjesecu lipnju 2013. godine među studentima stručnog studija Upravljanje u kriznim uvjetima na Veleučilištu Velika Gorica. Dosadašnja istraživanja su istaknula važnost proučavanja studentske populacije budući da obrazovne institucije imaju ključnu ulogu u razvoju i poticanju recikliranja (Clay, 2005; Stanić i Buzov, 2009) te da među mladim ljudima postoji veliki potencijal za oblikovanje ekološke svijesti (Cifrić i Čulig, 1987; Šundalić i Pavić, 2007). Značaj istraživanja studentske populacije u odnosu na ostalo stanovništvo proizlazi i iz toga što se radi o populaciji koja je tijekom obrazovanja, ali i putem medija, upućena u osnovne ekološke probleme i problematiku gospodarenja otpadom. Uzorak je brojio ukupno osamdeset i devet (89) slučajno odabranih studenata.

Izabrana je znanstveno istraživačka metoda ankete. Kao instrument ankete korišten je anketni upitnik: „Odvojeno prikupljanje otpada - navike i spoznaja“, koji se sastojao od dvadeset i dva (22) pitanja, dijelom otvorenog tipa, a dijelom višestrukog izbora. Rezultati su prikupljeni grupnim anketiranjem. Statističke metode korištene pri obradi podataka su deskriptivna statistika kao i metoda analitičke statistike. U obradi su primijenjene metode univarijatne (postoci) i bivarijatne analize (analiza varijance i t-test). Podaci i rezultati obrade podataka prikazani su tablično i grafički te se za obradu i prikaz rezultata istraživanja po pojedinim pitanjima koristiti frekvencija (f) i postotak (\%).

\section{ANALIZA REZULTATA ISTRAŽIVANJA}

\subsection{Obilježja uzorka}

Metodom ankete provedeno je istraživanje o razini svijesti o važnosti odvojenog prikupljanja otpada te gospodarenju otpadom među populacijom studenata Veleučilišta Velika Gorica.

Anketom je ispitano 89 slučajno odabranih studenata, od toga 37 ženskih $(41,6 \%)$ i 51 muška osoba $(57,3 \%)$ (jedna osoba nije naznačila spol). Od ukupnog broja ispitanika 
30 osoba $(33,7 \%)$ živi u stanu, a $59(67,3 \%)$ u obiteljskoj kući. Prosječna veličina kućanstva je 4,02 osobe $(S D=1,54)$. Distribucija uzorka s obzirom na broj osoba u kućanstvu (veličinu kućanstva) prikazana je na Slici 1.

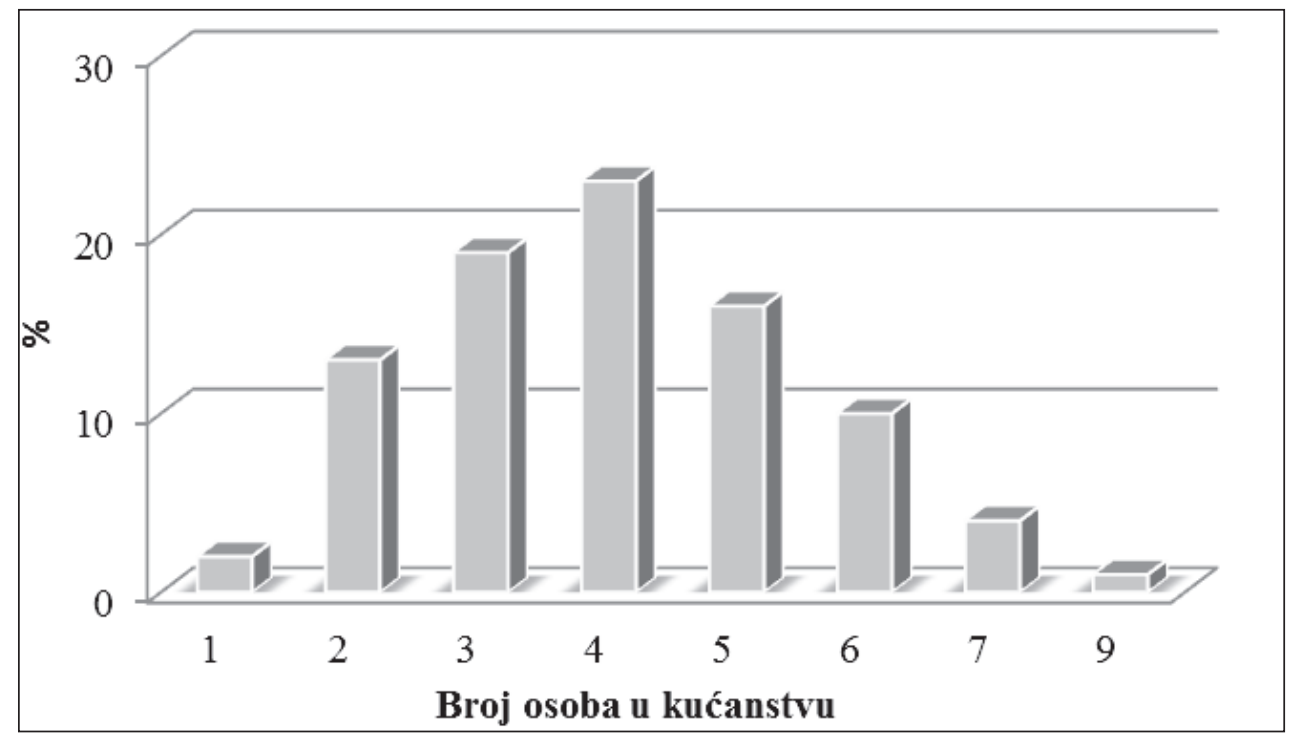

Slika 1. Distribucija uzorka u sobzirom na broj osoba u kućanstvu postocima ( $N=89)$

Gotovo cijelokupni uzorak ( $N=87,97,8 \%)$ percipira čovjeka kao glavnog uzročnika i izvor zagađenja. Samo dvije osobe percipiraju drugačije: jedna osoba smatra da su to prirodne pojave, a druga da je izvor zagađenja nešto loša organizacija gospodarenja otpadom (dakle, u stvari je i tu čovjek uzročnik zagađenja). Distribucija odgovora nalazi se na Slici 2.

\section{Prirodne \\ pojave; \\ $97,8 \%$}

Čovjek; $1,1 \%$

Nešto drugo;

$1,1 \%$

Slika 2. Distribucija percipiranih uzročnika zagadenja dobivena na uzorku od 89 ispitanika 
Od ispitanika je traženo da procjene koliko otpada nastaje u njihovom kućanstvu u razdoblju od jednog mjeseca. Najviše ispitanika, njih 28 (31,5\%), percipira da njihovo kućanstvo proizvodi između 25 i $49 \mathrm{~kg}$ otpada mjesečno, odnosno više od polovice uzorka $(55,1 \%)$ procjenjuje da njihovo kućanstvo proizvodi manje od $50 \mathrm{~kg}$ otpada u razdoblju od jednog mjeseca. Distribucija odgovora nalazi se na Slici 3.

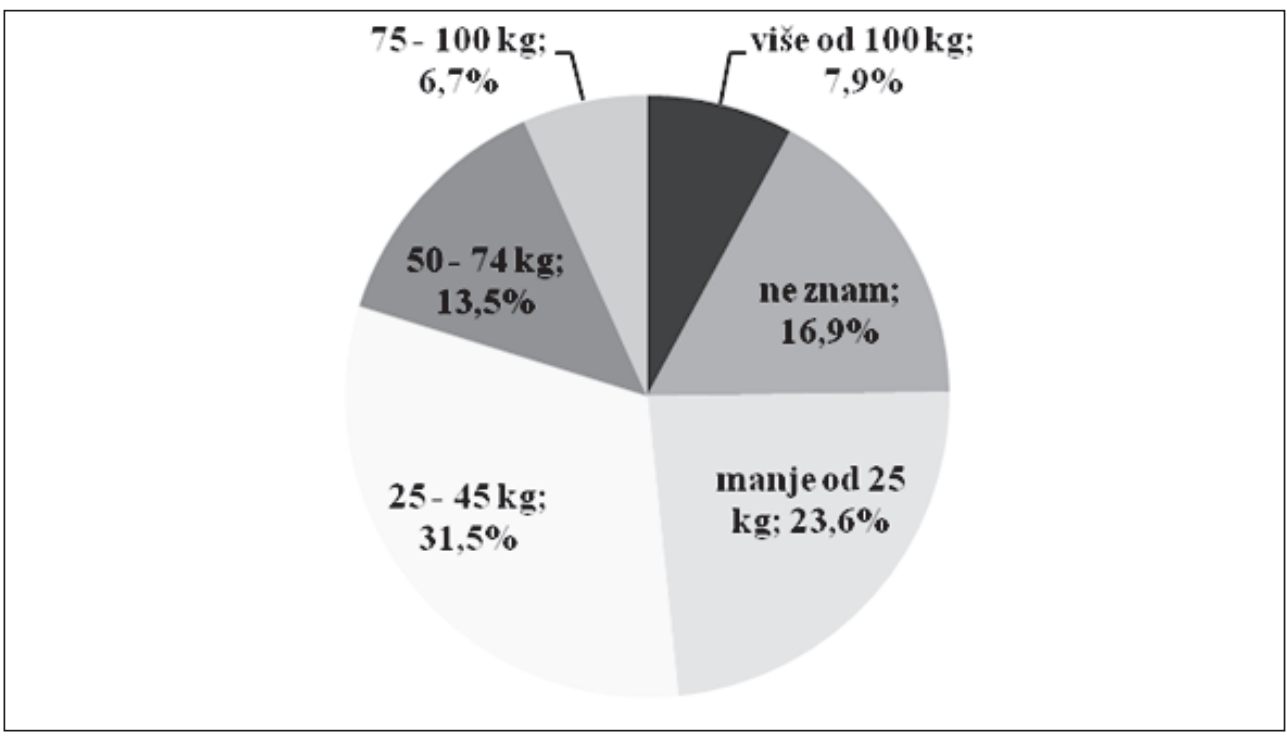

Slika 3. Procjena količine mjesečne proizvodnje otpada u vlastitom kućanstvu ( $N=89)$

Korelacija između procijenjene mjesečne količine otpada i broja osoba u kućanstvu iznosi $\mathrm{r}=0,4(\mathrm{p}<0,01)$ i ukazuje na umjerenu povezanost, $\mathrm{u}$ smislu da veće kućanstvo prati i veća mjesečna količina otpada. Iz izračuna korelacije izuzeti su ispitanici koji nisu mogli procijeniti količinu mjesečnog otpada svog kućanstva. Prema dostupnim podacima, svaki Hrvat godišnje u prosjeku proizvede $402 \mathrm{~kg}$ komunalnog otpada, što iznosi mjesečno 35,2 kg otpada po osobi (AZO, 2015). Uzevši u obzir navedeno i dobivene podatke o percipiranoj količini otpada u vlastitom kućanstvu vidljivo je da ispitanici znatno podcjenjuju količinu otpada koju njihova obitelj mjesečno proizvede.

Navedeno je dodatno provjereno T-testom. Analizirana je razlika između teoretske mjesečne količine otpada po kućanstvu i percipirane mjesečne količine otpada. Teoretska vrijednost izračunata je kao umnožak prosječne mjesečne količine otpada za jednu osobu i broja osoba u kućanstvu. Za percipiranu mjesečnu količinu otpada po kućanstvu uzeta je gornja vrijednost razreda (na primjer: ako je kategorija bila od 25,49 kg uzeta je maksimalna vrijednost od $49 \mathrm{~kg}$ ). Dobivena vrijednost $\mathrm{t}$-testa je $\mathrm{t}(72)=21,82 \mathrm{uz}$ statističku značajnost na razini od $1 \%(\mathrm{p}<0,01)$. Dakle i statistički postoji značajna razlika između percipirane količine mjesečne proizvodnje otpada po kućanstvu $(M=57,3 \mathrm{~kg}, S D=30,87,73)$ i one koju bi kućanstvo teoretski očekivano u prosjeku trebalo ostvariti $(M=95,7 \mathrm{~kg}, S D=37,49, N=73)$, u smislu da je percipirana količina znatno podcijenjena u odnosu na teoretski očekivanu. 


\subsection{Razvrstavanje otpada}

Od ukupnog uzorka 53,9\% (48) ispitanika je izjavilo da razvrstava otpad u vlastitom kućanstvu (Slika 4).

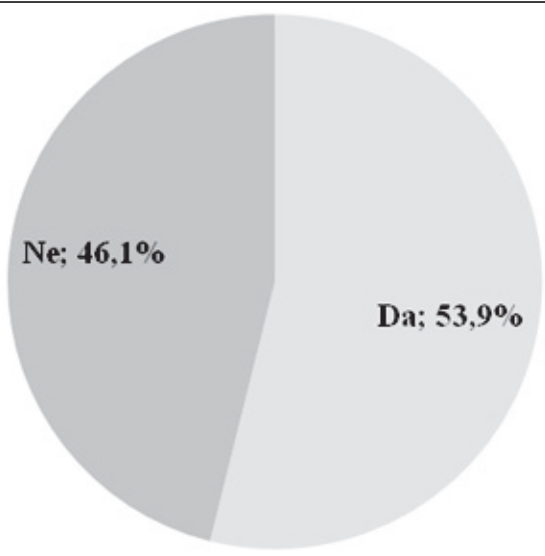

Slika 4. Razvrstavanje otpada u vlastitom kućanstvu ili na poslu $(N=89)$

Neparametrijskim hi-kvadrat testom testirano je postoji li statistički značajna razlika u razvrstavanju otpada $s$ obzirom na stambeni prostor u kojima ispitana osoba živi (stan ili obiteljska kuća), međutim nismo je potvrdili $\left(\chi^{2}(1)=0,282, p>0,05\right)$. Također, istim testom provjerena je statistička značajnost razlike u razvrstavanju otpada prema spolu. Niti ta razlika nije bila statistički značajna $\left(\chi^{2}(1)=0,011, p>0,05\right)$. Nadalje, pokazalo se da nema povezanosti između broja osoba u kućanstvu i razvrstavanja otpada, koeficijent korelacije iznosi $r=0,05$ i nije statistički značajan $(p>0,05, N=88)$. Na temelju statističkih pokazatelja dobivenih na uzorku može se zaključiti da razvrstavanje otpada ne ovisi o spolu, stambenom prostoru i veličini kućanstva, odnosno broju osoba u kućanstvu.

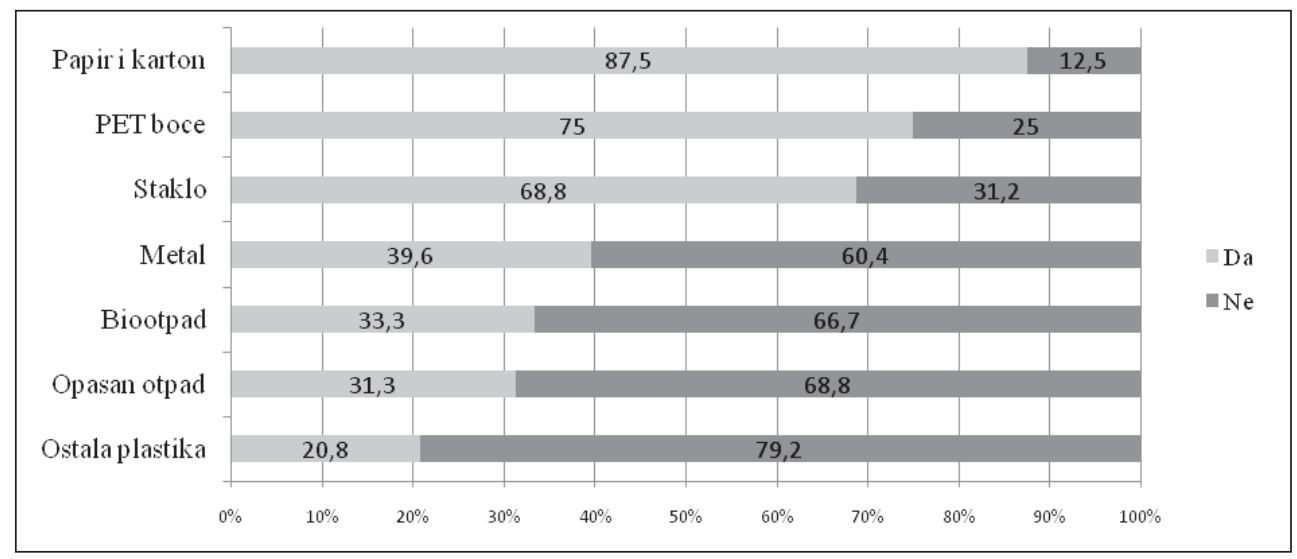

Slika 5. Postotak odvajanja pojedinih kategorija otpada $(N=48)$ 
Ispitanici koji su izjavili da razvrstavaju otpad pitani su koje uobičajene vrste otpada razvrstavaju. Pokazalo se da ispitanici koji razvrstavaju otpad u najvećoj mjeri odvajaju papir i karton $(87,5 \%)$, PET boce $(75 \%)$ i staklo $(68,8 \%)$, dok ostale vrste otpada razvrstava manje od $40 \%$. Drugim riječima, ispitanici najviše odvajaju one vrste otpada za koje postoji odgovarajuća infrastruktura za odvojeno prikupljanje u vidu dostupnih spremnika (papir, karton, PET boce, staklo i metal). Distribucija odgovora prema pojedinoj vrsti otpada nalazi se na Slici 5.

Tablica 1. Najčeści razlozi odvojenog prikupljanja otpada $(N=48)$

\begin{tabular}{|c|c|c|}
\hline Razlog & f & $\%$ \\
\hline $\begin{array}{l}\text { Upoznatost s činjenicom da je otpad vrijedna sirovina te da se recikliranjem } \\
\text { smanjuje eksploatacija prirodnih sirovina i štedi energija }\end{array}$ & 25 & 52,1 \\
\hline Doprinos smanjenju onečišćenja okoliša & 23 & 47,9 \\
\hline $\begin{array}{l}\text { Svjesnost da je moguće smanjiti količinu otpada koji se odlaže na odlagališta } \\
\text { odvajajući otpad u svome kućanstvu }\end{array}$ & 17 & 35,4 \\
\hline Neki drugi razlog: & 7 & 14,6 \\
\hline zarada prodajom otpada & 2 & 4,2 \\
\hline mislim da je to u redu & 1 & 2,1 \\
\hline zato jer postoji organiziran odvoz otpada & 1 & 2,1 \\
\hline zato što moram & 1 & 2,1 \\
\hline iz dosade & 1 & 2,1 \\
\hline bez specificiranog razloga & 1 & 2,1 \\
\hline
\end{tabular}

Upoznatost s činjenicom da je otpad vrijedna sirovina te da se recikliranjem smanjuje eksploatacija prirodnih sirovina i štedi energija

Doprinos smanjenju onečišćenja okoliša

Svjesnost da je moguće smanjiti količinu otpada koji se odlaže na odlagališta odvajajući otpad u svome kućanstvu

Neki drugi razlog

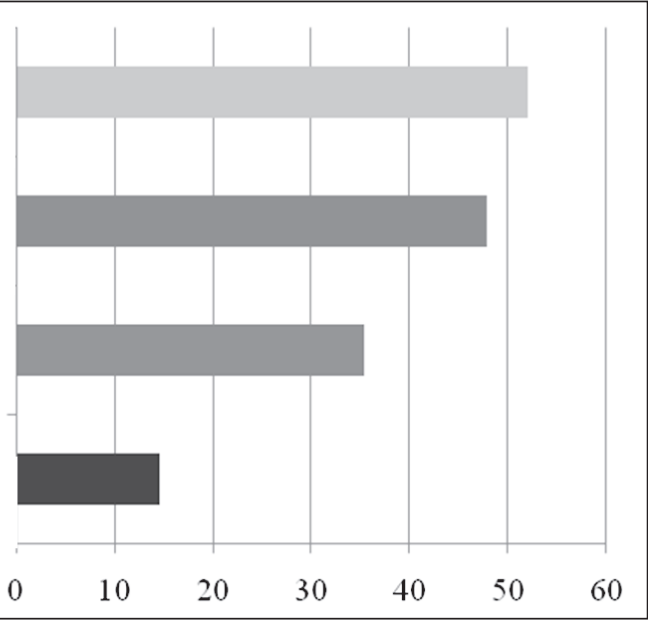

Slika 6. Najčešći razlozi odvojenog prikupljanja otpada $(N=48)$

Ispitanicima koji razvrstavaju otpad ponuđena su tri razloga za odvojeno prikupljanje otpada s pretpostavkom da su najčešća:

1. Svjesnost da je moguće smanjiti količinu otpada koji se odlaže na odlagališta odvajajući otpad u svome kućanstvu, 
2. Upoznatost s činjenicom da je otpad vrijedna sirovina te da se recikliranjem smanjuje eksploatacija prirodnih sirovina i štedi energija, i

3. Doprinos smanjenju onečišćenja okoliša.

Ponuđena je i četvrta, slobodna opcija ukoliko tri navedena ne obuhvaćaju sve pa je traženo od ispitanika da sami navedu neki drugi razlog ukoliko ga imaju. Svi razlozi osim slobodne opcije su podjednako zastupljeni. Prikaz odgovora nalazi se u Tablici 1. i na Slici 6. Rezultati se odnose samo na onaj dio uzorka koji se izjasnio da odvaja otpad. Dosadašnja istraživanja povezanosti znanja o okolišu i zbrinjavanja otpada pokazuju značaj znanja i motivacija kada je riječ o motivu za sudjelovanje u recikliranju, pa pojedinci koji su svjesniji važnosti recikliranja, te više znaju o materijalima koji se recikliraju i načinima recikliranja, češće participiraju u recikliranju (Vining, 1990).

Tablica 2. Najčesći razlozi nerazvrstavanja otpada $(N=41)$

\begin{tabular}{|l|c|c|}
\hline \multicolumn{1}{|c|}{ Razlog } & f & $\%$ \\
\hline $\begin{array}{l}\text { Nepostojanje zelenih otoka / kontejnera za odvojeno prikupljanje otpada u } \\
\text { blizini mjesta stanovanja }\end{array}$ & 26 & 63,4 \\
\hline Nedostatak vremena & 12 & 29,3 \\
\hline Nepostojanje financijske naknade za odvojeno prikupljanje otpada i & 3 & 7,3 \\
\hline Mišljenje da nije potrebno razvrstavati otpad & 1 & 2,4 \\
\hline Neki drugi razlog: & 4 & 9,8 \\
neinformiranost o važnosti odvajanja otpada & 1 & 2,4 \\
nemam naviku odvajanja otpada (ali promijenit ću se) & 1 & 2,4 \\
nisam razmišljao o tome & 1 & 2,4 \\
bez specificiranog razloga & 1 & 2,4 \\
\hline
\end{tabular}

Nepostojanje zelenih otoka/kontejnera za odvojeno prikupljanje otpada u blizini mjesta stanovanja

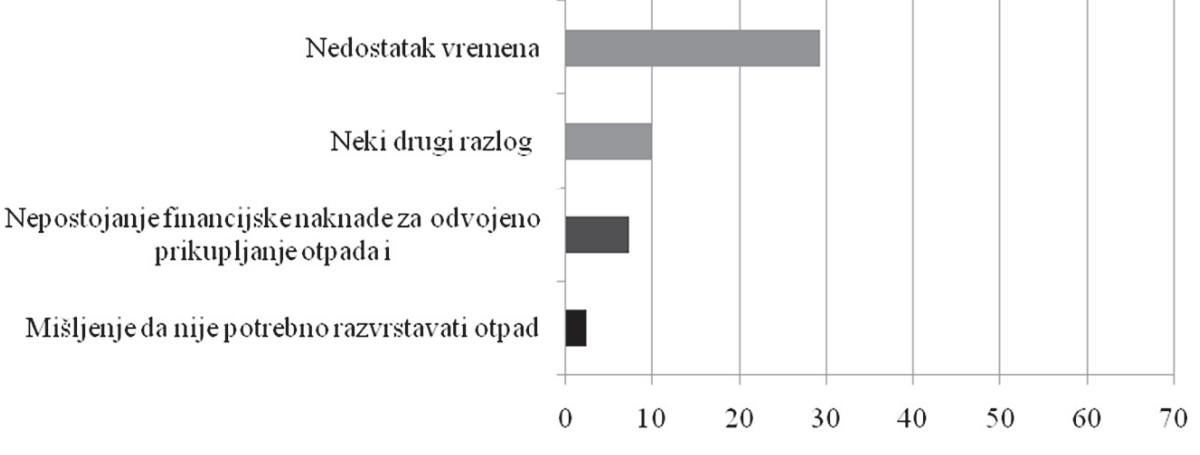

Slika 7. Najčešcí razlozi neodvajanja otpada $(N=41)$

Svakako je zanimljivo pogledati razloge za nerazvrstavanje kod onog dijela ispitanika koji su odgovorili da ne razvrstavaju otpad $(N=41,4,61 \%)$. Pretpostavljena su četiri najčešća razloga: 
1. nedostatak vremena,

2. nepostojanje zelenih otoka / kontejnera za odvojeno prikupljanje otpada u blizini mjesta stanovanja,

3. nepostojanje financijske naknade za odvojeno prikupljanje otpada i

4. mišljenje da nije potrebno razvrstavati otpad

Ponuđena je i peta, slobodna opcija odgovora gdje su ispitanici trebali sami navesti razlog ukoliko ga imaju. Rezultati su prikazani u Tablici 2 i na Slici 7.

\subsection{Percepcija infrastrukture gospodarenja otpadom}

Cjelovit sustav gospodarenja otpadom temelji se na principu hijerarhijskog koncepta u kojem se na vrhu nalazi izbjegavanje otpada, a potom slijedi vrednovanje i odlaganje. Primjenom primarne reciklaže i vraćanjem otpada u proizvodni proces ostvaruju se velike uštede sirovina i energenata. To je svakako najvažniji korak u cjelokupnom sustavu gospodarenja otpadom jer se na mjestu nastanka osigurava izdvajanje vrijednih resursa koji ulaze u tokove reciklaže posebnih kategorija otpada stoga su ispitanicima postavljena pitanja vezana uz postojeću infrastrukturu gospodarenja otpadom u njihovom gradu ili općini. Preciznije, pitanja se odnose na postojanje i dostupnost raspoloživih spremnika za odvojeno prikupljanje otpada te na aktivnosti komunalnih službi zaduženih za gospodarenje otpadom. Najviše ispitanika je navelo da se u njihovom susjedstvu odvozi otpad jednom tjedno $(38,2 \%)$, tek nešto manje je navelo da se otpad odvozi dvaput tjedno $(37,1 \%)$. Tri puta tjedno se odvozi otpad u susjedstvu kod 19,1\% ispitanika, a četiri puta u susjedstvu za svega 5,6\% ispitanika.

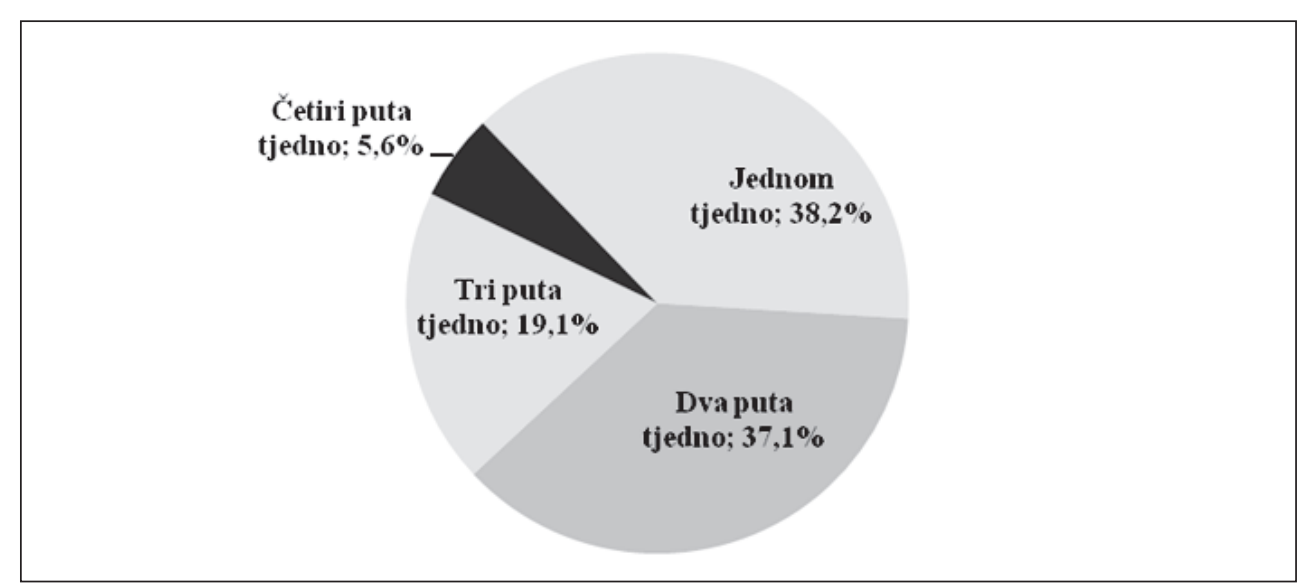

Slika 8. Učestalost odvoza komunalnog otpada $(N=89)$

Od ukupnog broja ispitanika 77,5\% navodi kako u njihovom gradu ili općini postoji odlagalište otpada. Zabrinjavajuća je činjenica da je 73,1\% ispitanika ustvrdilo kako u blizini njihovog kućanstva nema dovoljno kontejnera za odvojeno skupljanje otpada. Od 73,1\% do 78,7\% izjavljuje da u blizini njihovog kućanstva nema zasebnih kontejnera za pojedine vrste otpada, a najmanje je kontejnera za biootpad ( $91 \%$ ispitanika izjavilo je da kontejneri za biootpad u njihovoj blizini ne postoje). Također, otprilike 
dvije trećine ispitanika tvrdi kako ne zna gdje može dobiti informacije o održivom gospodarenju otpadom te kako nema dovoljno javnih informacija o razvrstavanju otpada u općini ili gradu boravka (Slika 9).

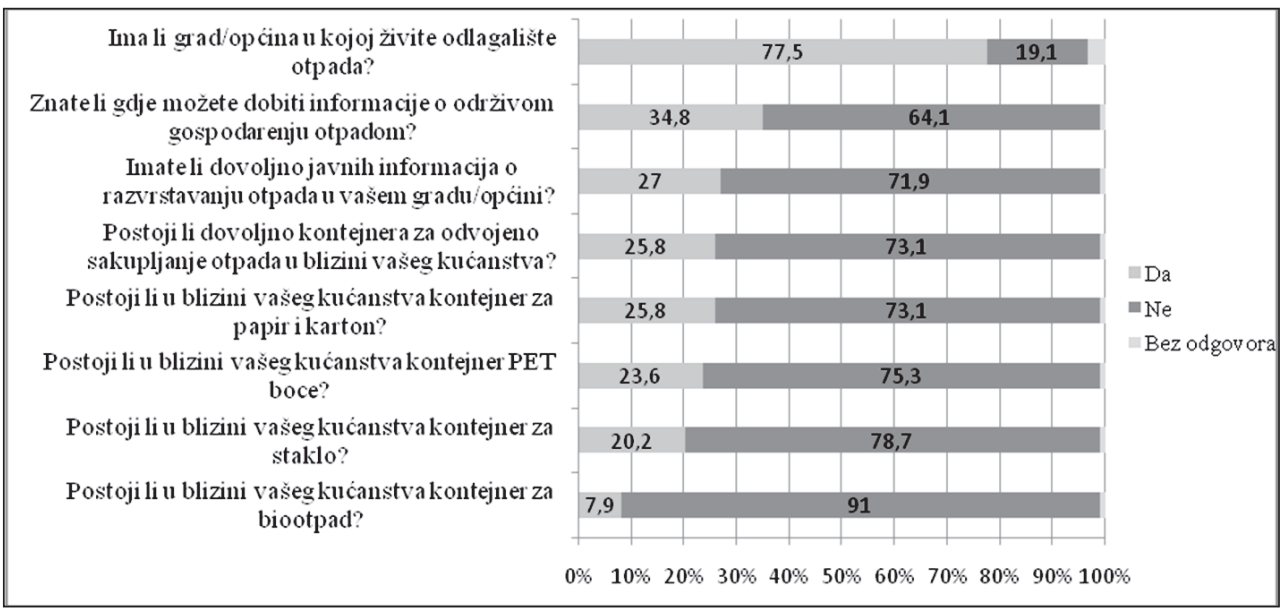

Slika 9. Percepcija o dostupnosti informacija $i$ infrastrukture o odvojenom gospodarenju otpadom

Iako navedeni podaci predstavljaju percepciju ispitanika te ne predstavljaju nužno realnu infrastrukturu gospodarenja otpadom već aproksimaciju realnog stanja, može se zaključiti da podaci govore o nedostupnosti informacija i nedovoljnom oglašavanju, odnosno da je edukacija stanovništva o mogućnostima odvojenog prikupljanja otpada na niskoj razini te da postoji prostor za poboljšanje u smislu marketinških aktivnosti i jačanja infrastrukture gospodarenja otpadom. Kao dodatni argument navedenom su podaci iz Tablice 3. koja prikazuje odgovore manjine ispitanika, njih 31 koji su izjavili da znaju gdje mogu dobiti informaciju o održivom gospodarenju otpadom. Dobivene informacije ostavljaju dojam da se radi više o osobnoj motivaciji i angažiranosti ispitanika da pronađu i dobiju tražene informacije nego o realno svima dostupnim informacijama.

Tablica 3. Dostupni izvori informacija o gospodarenju otpadom

\begin{tabular}{|l|c|}
\hline \multicolumn{1}{|c|}{ Izvor informacija o gospodarenju otpadom } & f \\
\hline nisu naveli izvor & 17 \\
\hline internet & 9 \\
\hline općina & 4 \\
\hline dnevni tisak, javna glasila i lokalni listovi & 2 \\
\hline komunalno poduzeće & 2 \\
\hline oglasni letci i panoi & 1 \\
\hline eko škola & 1 \\
\hline kolegij Gospodarenje otpadom & 1 \\
\hline
\end{tabular}


Ispitanici su također pitani o iskustvu odnošenja otpada u reciklažno dvorište. Nešto manje od trećine (27\%) ispitanika redovito odvozi otpad u reciklažno dvorište. Ostali nemaju takav običaj, a $28,1 \%$ ispitanika to opravdava postojanjem spremnika za sve vrste otpada koje odvojeno sakupljaju u blizini njihovog mjesta stanovanja, 29,2\% izjavljuje da nikada nije odvajalo otpad, a 6,7\% ne zna što je reciklažno dvorište (Slika 10).

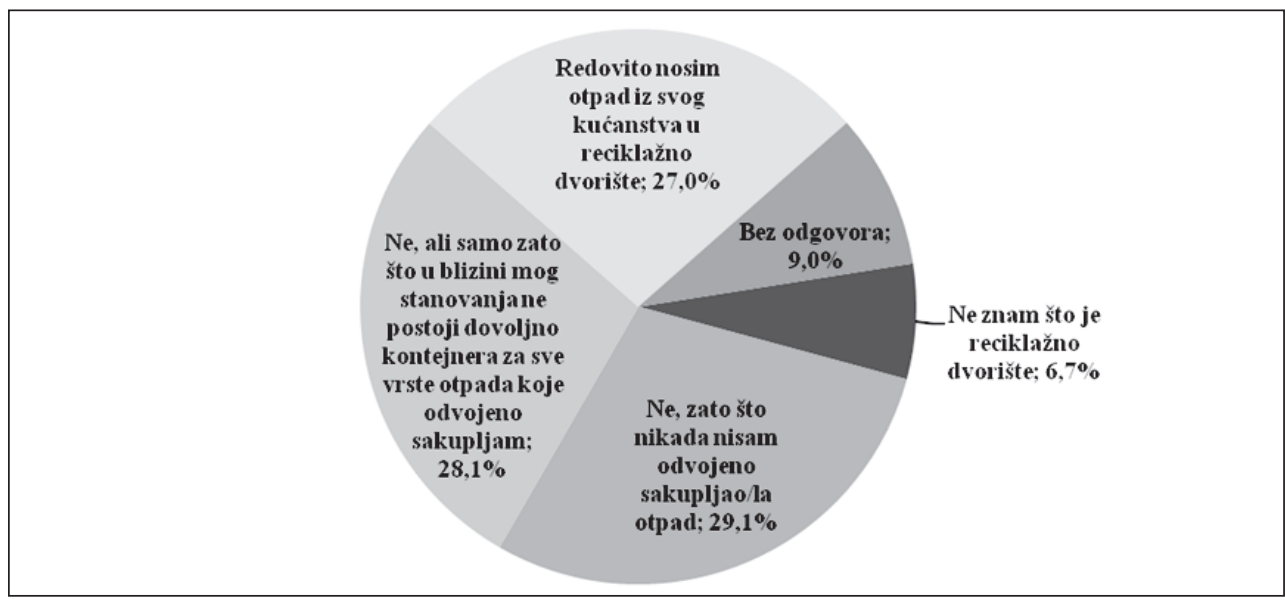

Slika 10. Navike ispitanika ( $N=89)$ vezano uz odnošenje otpada u reciklažna dvorišta

\subsection{Unaprjedenje sustava gospodarenje otpadom u Republici Hrvatskoj}

Posebnim setom pitanja istraženo je da li ispitanici smatraju da je sustav gospodarenja otpadom u Hrvatskoj potrebno unaprijediti te koliko su ispitanici spremni na vlastiti angažman u pogledu odvojenog prikupljanja otpada. Pokazalo se da najviše ispitanika $(46,1 \%)$ smatra da je potrebna bolja infrastruktura za zbrinjavanje otpada, no i da tek nešto manje njih $(42,7 \%)$ smatra kako je potrebna temeljita promjena sustava. Velik broj ispitanika, njih 33,7\% također smatra da je potrebno više informirati javnost o mogućnosti odvojenog prikupljanja otpada, a samo jedan ispitanik $(1,1 \%)$ smatra da sustav funkcionira kako treba (Slika 11).

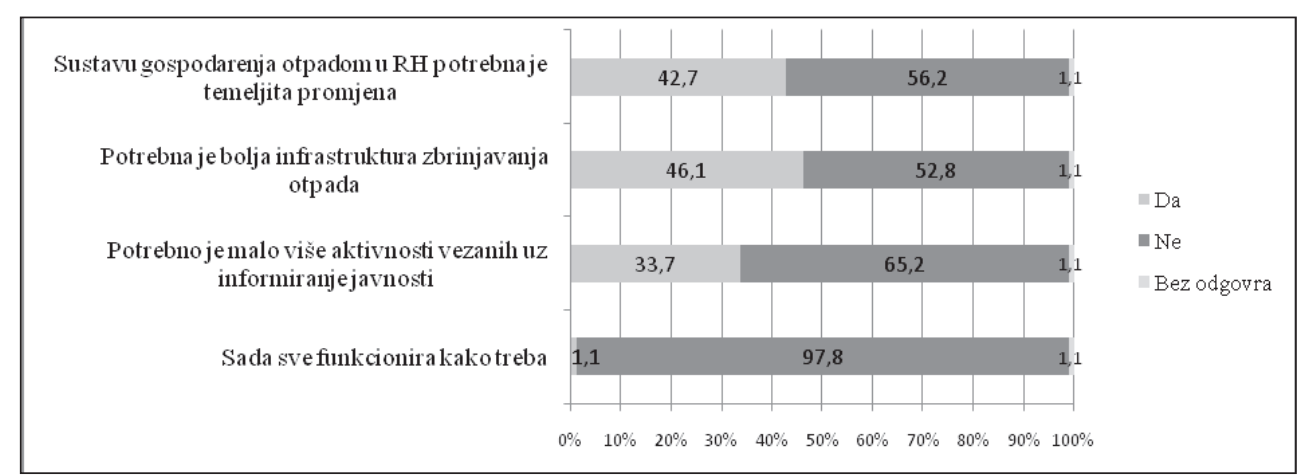

Slika 11. Odgovori ispitanika $(N=89)$ na pitanje: ,Smatrate li da sustav gospodarenja otpadom u Hrvatskoj treba unaprijediti?" 
U tom kontekstu postavljena su pitanja koja su podrazumijevala voljnost za podršku organiziranijem sustavu gospodarenja otpadom. Uključena su pitanja koja su podrazumijevala materijalni aspekt, odnosno pristanak na više cijene naknade za komunalne usluge. Gotovo svi ispitanici $(94,4 \%)$ su izjavili da su spremni podržati organiziraniji sustav gospodarenja otpadom i odvojeno prikupljati otpad (Slika 12).

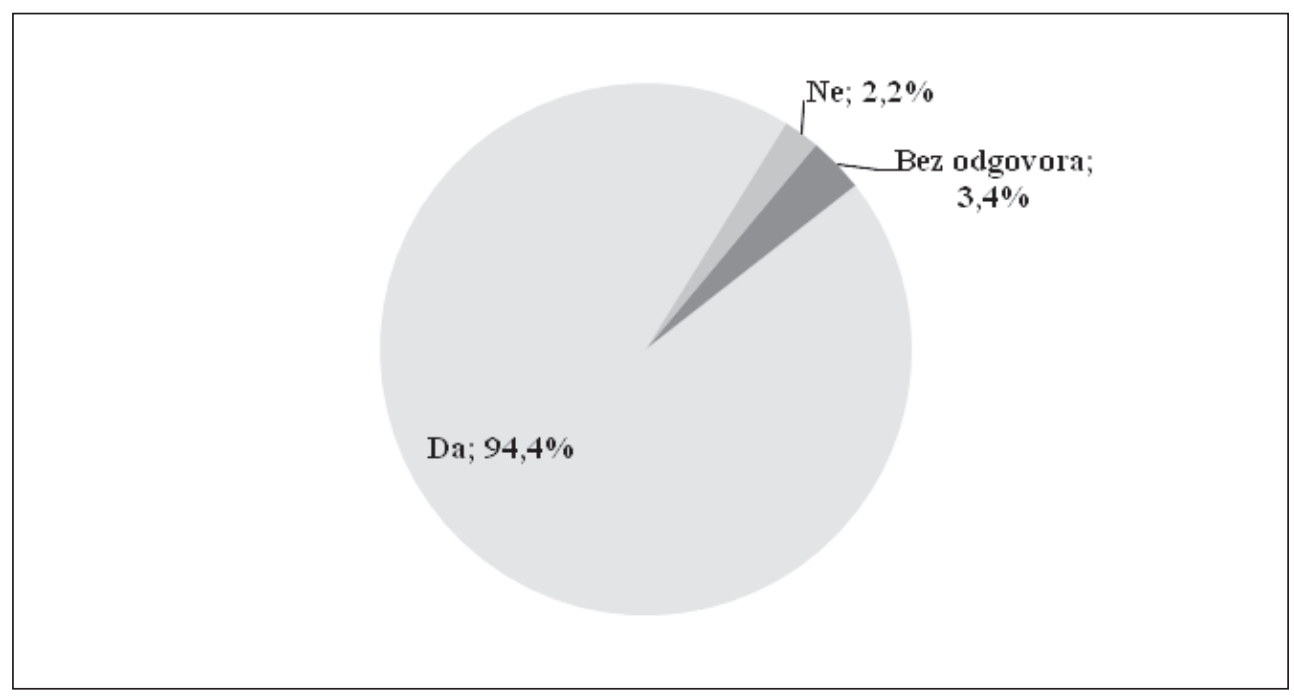

Slika 12. Odgovori ispitanika ( $N=89)$ na pitanje: „Biste li podržali organiziraniji sustav gospodarenja otpadom te odvojeno prikupljali otpad?"

Ipak, pokazalo se da gotovo polovica (49,5\%), ispitanih ne želi plaćati nikakvu naknadu za poboljšanje infrastrukture gospodarenja otpadom, a većina $(56,2 \%)$ je spremna plaćati neku naknadu, ako bi to povećalo količinu odvojeno sakupljenog otpada i to s tendencijom ka plaćanju najniže moguće naknade do 50 kn godišnje (Slika 13). Računavši prosjek visine naknade samo na dijelu uzorka koji je bio spreman plaćati naknadu dobili smo vrijednost $M^{1}=1,54\left(S D^{2}=0,65, N^{3}=50\right)$ koja odgovara drugoj ponuđenoj cjenovnoj kategoriji, tj. od 50 do 100 HRK godišnje. Međutim dominantno najbrojnija cjenovna kategorija bila je do 50 HRK godišnje $\left(D^{4}=1\right)$, uzevši u obzir i da je najviše ljudi u pojedinoj kategoriji bio onih koji ne žele uopće plaćati naknadu. Stoga je realno zaključiti da bi eventualno najprihvatljivija naknada trebala iznositi najviše do $50 \mathrm{HRK}$ godišnje.

$1 M$-aritmetička sredina, u ovom slučaju se odnosi na prosjek od tri ponuđene cijenovne kategorije, dakle prosjek ordinalnih vrijednosti $(1=$ do 50 HRK godišnje, $2=$ od 50 do 100 HRK godišnje, 3 = više od 100 HRK godišnje)

$2 S D$ - standardna devijacija, mjera raspršenja rezultata - prosječno odstupanje rezultata od aritmetičke sredine $3 N$ - broj ispitanika uzet u obzir

$4 D$ - dominantna vrijednost, rezultat koji se pojavljuje najveći broj puta. U ovom slučaju se odnosi na jednu od tri ponuđene cijenovne kategorije za koju se najveći broj ispitanika odlučio 


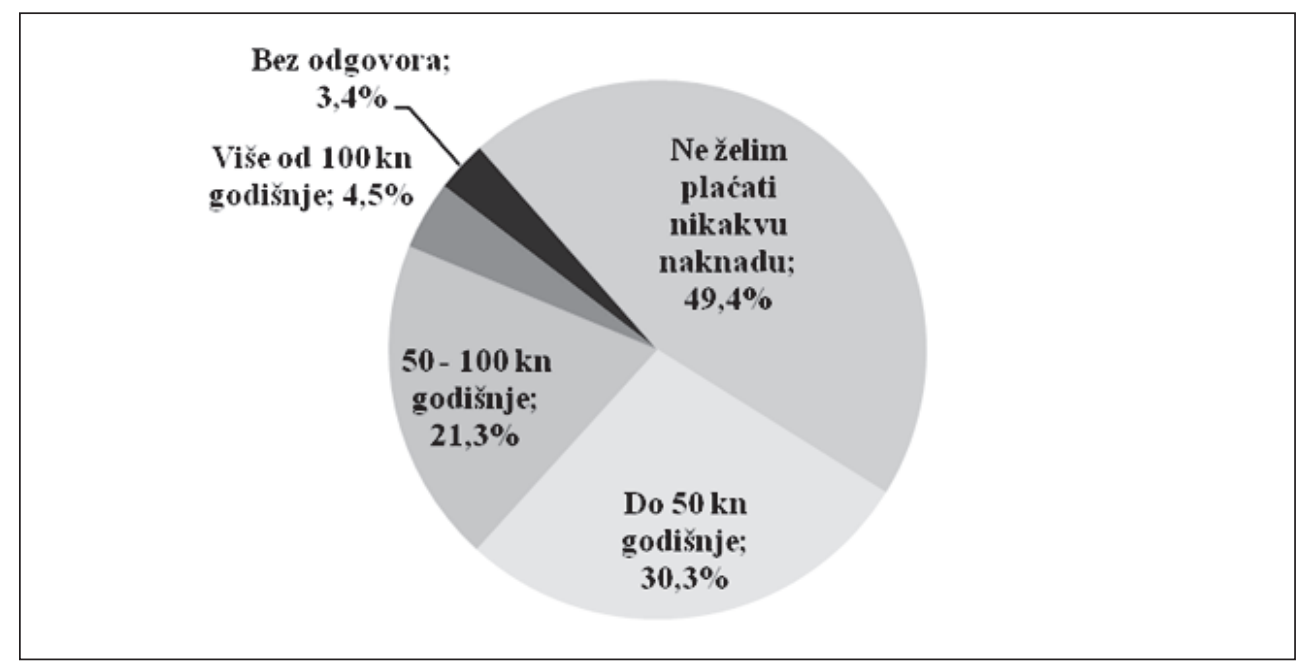

Slika 13. Spremnost ispitanika $(N=89)$ na plaćanje naknade za poboljšanje infrastrukture gospodarenja otpadom

S druge strane 40,4\% ispitanika smatra da bi trebali primati naknadu kako bi odvojeno prikupljali otpad, što je donekle sličan postotak onom u koji spadaju ispitanici koji ne žele plaćati naknadu za odvojeno prikupljanje otpada (Slika 14).

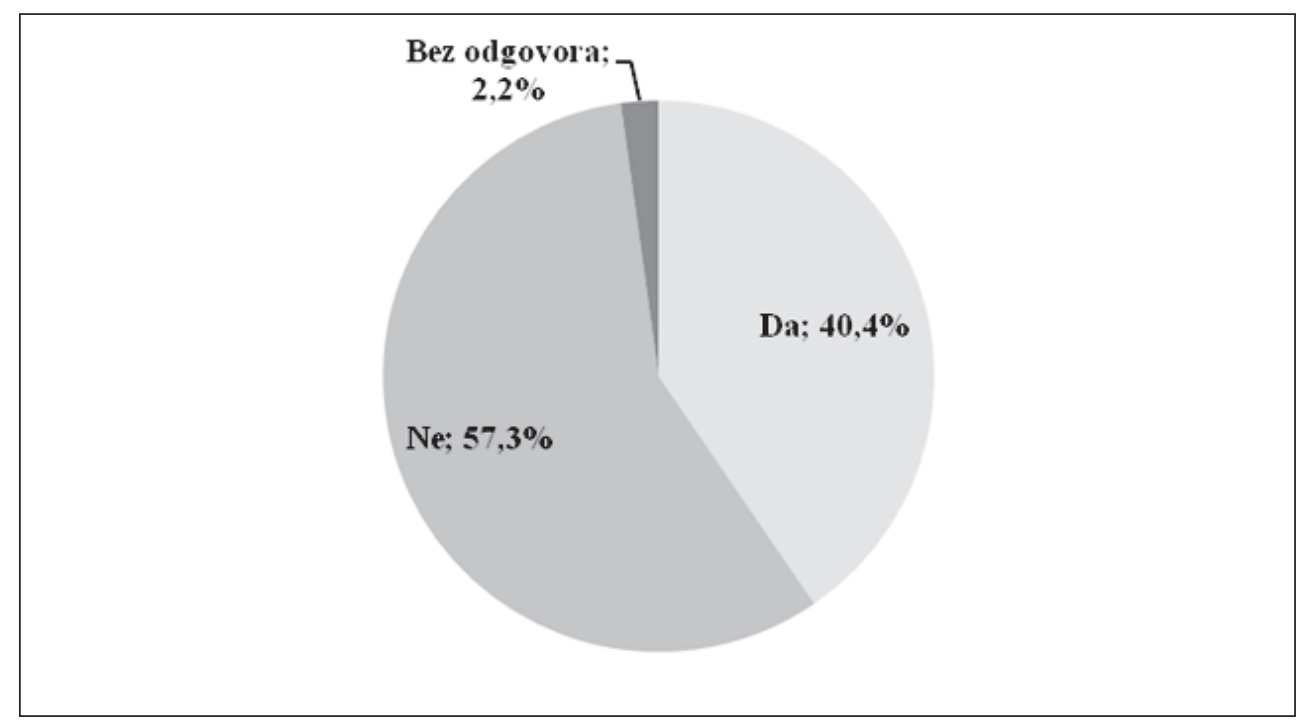

Slika 14. Odgovori ispitanika $(N=89)$ na pitanje „Smatrate li da biste trebali dobivati naknadu za odvojeno prikupljanje otpada?"

Međutim većina $(87,6 \%)$ izjavljuje kako bi odvojeno prikupljala otpad kada bi time umanjili iznos računa za komunalne usluge (Slika 15). 


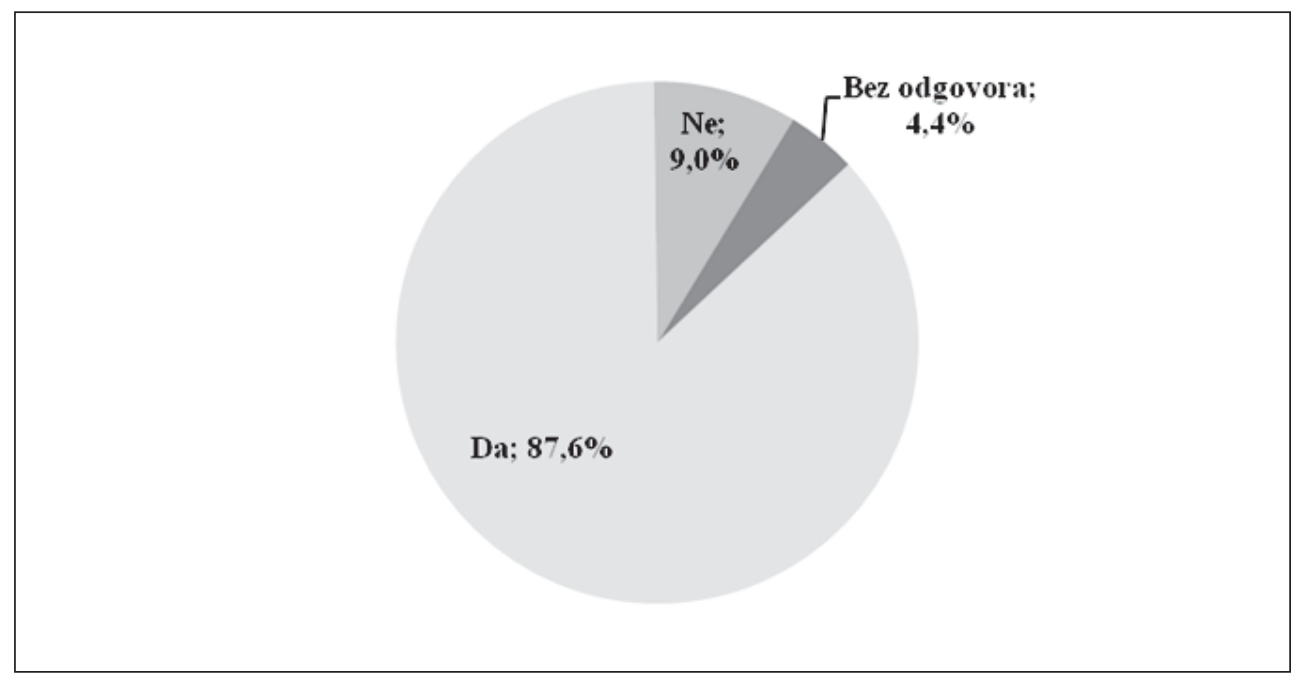

Slika 15. Odgovori ispitanika $(N=89)$ na pitanje „Biste li odvojeno prikupljali otpada kada biste time smanjili iznos računa za komunalne usluge?"

Ispitanici su pitani i koliko bi to umanjenje trebalo iznositi. Najviše ih je izjavilo kako bi odvajali otpad bez obzira na umanjenje računa $(43,8 \%)$, dok od ostalih koji inzistiraju na umanjenju naknade, očekivano najveći broj njih (21,3\%), traži najveće moguće predloženo umanjenje (više od 100 HRK godišnje). Izračunato prosječno, samo za ispitanike koji inzistiraju na umanjenju, taj iznos odgovara drugoj cjenovnoj kategoriji umanjenja naknade $(M=2,06, S D=0,87, N=47)^{5}$ u visini od 50 do 100 HRK godišnje. Dominantno, preferirano umanjenje naknade je više od 100 HRK godišnje $\left(D^{6}=3\right)$. Uzevši u obzir kako je ipak najveći broj ljudi izjavio kako je spreman odvajati otpad i bez umanjenja naknade prihvatljiva visina umanjenja naknade bila bi ipak nešto niža, odnosno između 50 i 100 HRK godišnje.

\section{ZAKLJUČNO RAZMATRANJE}

Učestalost odvajanja pojedinih kategorija otpada među ispitanicima je niska budući da $53.9 \%$ ispitanika razvrstava otpad u vlastitom kućanstvu i to najviše odvajaju one vrste otpada za koje postoji odgovarajuća infrastruktura za odvojeno prikupljanje u vidu do-

$5 M$ - aritmetička sredina, u ovom slučaju se odnosi na prosjek od tri ponuđene cijenovne kategorije, dakle prosjek ordinalnih vrijednosti $(1=$ do 50 HRK godišnje, $2=$ od 50 do 100 HRK godišnje, 3 = više od 100 HRK godišnje)

$S D$ - standardna devijacija, mjera raspršenja rezultata - prosječno odstupanje rezultata od aritmetičke sredine

$N$ - broj ispitanika uzet u obzir

$6 \mathrm{D}$ - dominantna vrijednost, rezultat koji se pojavljuje najveći broj puta. U ovom slučaju se odnosi na jednu od tri ponuđene cijenovne kategorije za koju se najveći broj ispitanika odlučio 
stupnih spremnika (papir i karton (87,5\%), PET boce (75\%) i staklo (68,8\%)). Zabrinjavajuća je činjenica da je 73,1\% ispitanika ustvrdilo kako u blizini njihovog kućanstva nema dovoljno kontejnera za odvojeno skupljanje otpada. Stoga, iako je zakonodavni dio riješen, sustav gospodarenja otpadom u Republici Hrvatskoj ne funkcionira u potpunosti. Infrastruktura koja treba podržati dobro zamišljen sustav gospodarenja otpadom je nedostatna ili se ne koristi na zadovoljavajući način. Velik pomak bi se napravio kada bi se organizirao sustav razvrstavanja otpada na razini kućanstva koja bi tako odvojeno skupljala otpad namijenjen oporabi (papir, staklo, PET, limenke, staro željezo itd.) ili posebnoj obradi (baterije, ulja, bio-otpad, lijekovi) u odgovarajuće spremnike. Oko dvije trećine ispitanika se izjasnilo kako ne zna gdje može dobiti informacije o održivom gospodarenju otpadom te kako nema dovoljno javnih informacija o razvrstavanju otpada u općini ili gradu boravka. Sudjelovanje građana u zbrinjavanju otpada vrlo je važno, stoga je stalna edukacija, informiranje i obrazovanje te poticanje na promjene $\mathrm{u}$ ponašanju vezano uz odvojeno prikupljanje otpada preduvjet da bi se to postiglo. Time bi se stvorio osjećaj odgovornosti za zbrinjavanje otpada od pojedinca do globalnih razina. Također se pokazalo da gotovo polovica $(49,5 \%)$ ispitanih ne želi plaćati nikakvu dodatnu naknadu, dok je većina $(56,2 \%)$ ipak spremna plaćati neku naknadu za poboljšanje infrastrukture gospodarenja otpadom, ako bi to povećalo količinu odvojeno sakupljenog otpada, i to s tendencijom ka plaćanju najniže moguće naknade do $50 \mathrm{kn}$ godišnje. Sukladno članku 33. Zakona o održivom gospodarenju otpadom obveza za davatelja javne usluge prikupljanja miješanog komunalnog otpada je obračunavati cijenu korisniku usluge razmjerno količini predanog otpada u obračunskom razdoblju, pri čemu je kriterij količine otpada masa predanog otpada ili volumen spremnika otpada i broj pražnjenja spremnika. Stoga je za očekivati da će primjena Zakona o održivom gospodarenju otpadom u dijelu koji se odnosi na naplatu usluge prikupljanja miješanog komunalnog otpada imati vrlo dobar učinak na povećanje količine odvojeno prikupljanog otpada, budući većina ispitanika $(87,6 \%)$ tvrdi kako bi odvojeno prikupljala otpad kada bi time umanjili iznos računa za komunalne usluge.

\section{LITERATURA}

Agencija za zaštitu okoliša (AZO). (2015). Izvješče o komunalnom otpadu za 2013. godi$n u$. Zagreb: Agencija za zaštitu okoliša.

Cifrić, I. (1999). Percepcija društva i okoliša: desetljeće poslije. Nekoliko usporednih pokazatelja istraživanja 1986. i 1998. Socijalna ekologija, 8(3): 193-223.

Cifrić, I. (2005). Ekološka zabrinutost. Percepcija ekoloških problema kao zabrinjavajućih. Socijalna ekologija, 14(1-2): 1-28.

Cifrić, I. (2008). Koliko nas zabrinjavaju ekološki problemi. U: Cifrić, I. (ur.), Relacijski identiteti. Prilozi istraživanju identiteta hrvatskog društva (str. 221-244). Zagreb: Hrvatsko sociološko društvo i Institut za društvena istraživanja.

Cifrić, I. i Čulig, B. (1987). Ekološka svijest mladih. Zagreb: Radna zajednica RHSSOH 
i Zavod za sociologiju Filozofskog fakulteta.

Clay, S. (2005). Increasing University recycling: factors influencing recycling behaviour among students at Leeds University. Earth \& Environment, 1: 186-228.

De Coverly, E., McDonagh, P., O'Malley, L. i Patterson, M. (2008). Hidden Mountain - The Social Avoidance of Waste. Journal of Macromarketing, 28(3): 289-303.

Ebreo, A., Hershey, J. i Vining, J. (1999). Reducing Solid Waste: Linking Recycling to Responsible Consumerism. Environment and Behavior, 31(1): 107-135.

Ebreo, A. i Vining, J. (2001). How similar are recycling and waste reduction? Environment and Behavior, 33(3): 424-448.

Evison, T. i Read, A. D. (2001). Local Authority recycling and waste awareness publicity / promotion. Resources, Conservation \& Recycling, 32: 275-291.

Hazen, D. (2005). The Hidden Life of Garbage. Intervju s H. Rogers. Alternet. URL: http://www.alternet.org/story/27456/?page=2 (02.09.2014.)

Stanić, S. i Buzov, I. (2009). Recikliranje i zbrinjavanje otpada - Stavovi i aktivnosti studenata. Godišnjak Titius: godišnjak za interdisciplinarna istraživanja porječja Krke, 2(2): 275-296.

Stanić, S., Buzov, I. i Galov, M. (2009). Prakse urbanog stanovništva u zbrinjavanju kućanskog otpada. Socijalna ekologija, 18(2): 130-156.

Šundalić, A. i Pavić, Ž. (2007). Ekološka svijest mladih između održivog razvoja i tehnocentrizma. Socijalna ekologija, 16(4): 279-296.

Van Houtven, G. L. i Morris, G. E. (1999). Household behaviour under alternative pay-as you-throw systems for solid waste disposal. Land Economics, 75(4): 515-537.

Vincente, P. i Reis, E. (2008). Factors Influencing Households Participationin Recycling. Waste Management \& Research, 26(2): 140-146.

Vining, J. (1990). What Makes a Recycler? Environment and Behavior, 22(1): 55-73. 


\title{
PERCEPTION OF ISSUES, POSSIBILITIES AND HABITS OF SEPARATE WASTE COLLECTION
}

\author{
Sanja Kalambura, Aleksandar Racz, Nives Jovičić and Marko Toth
}

\begin{abstract}
Integrated waste management system is based on the principle of hierarchy, where the avoidance of waste is on top, followed by waste evaluation, and only then by waste disposal. It is estimated that only a small portion of waste generated in Croatia over the period of one year finds its way to recovery. The remainder of waste, measured in millions of tons per year, is disposed. Previous studies, which are discussed in this paper, also demonstrate the significance of examining this important topic.

In this study, group questionnaires were used to investigate the awareness of the importance of waste collection and waste management. The main aim of the study was to investigate the perception of separate waste collection. The results were analysed using descriptive and analytical statistics, i.e. univariate (percentages) and bivariate analysis (analysis of variance and t-test). The results reveal that more than one half of the respondents separate waste in their own households, and those who do not separate it give as their main reason the lack of available infrastructure for separate waste collection close to home.
\end{abstract}

Keywords: ecological awareness, perception, waste, waste separation, waste collection, recycling

\section{WAHRNEHMUNG DES PROBLEMS, MÖGLICHKEITEN UND GEWOHNHEITEN DER GETRENNTEN ABFALLSAMMLUNG}

\author{
Sanja Kalambura, Aleksandar Racz, Nives Jovičić und Marko Toth
}

\begin{abstract}
Zusammenfassung
Die integrierte Abfallwirtschaft beruht auf dem Konzept der Hierarchie, bei dem die Abfallvermeidung an der Spitze liegt, dann folgt die Wiederverwertung und erst am Ende die liegt die Beseitigung. Es wird geschätzt, dass nur ein kleiner Anteil von in einem Jahr entstandenen Gesamtabfall in der Republik Kroatien wiederverwertet wird. Alles andere, Millionen Tonnen jährlich, wird beseitigt. Laut bisherigen Studien, die in der Arbeit angeführt sind, wird das Abfallproblem als wichtig wahrgenommen.

Das Ziel der Forschung war es, über die aktuelle Wahrnehmung der getrennten Abfallsammlung zu erfahren und die Forschungsergebnisse, sowie deren statistische Berabeitung wurden in der Arbeit präsentiert. Die Resultate wurden durch Gruppenumfragen gesammelt. Bei der Datenverarbeitung wurden die deskriptive Statistik und die Methode der analytischen Statistik angewandt. Es wurden Methoden der univariaten (Prozente) und der bivariaten Analyse (Varianzanalyse und T-Test) angewandt. Die Resultate haben gezeigt, dass mehr als die Hälfte der Befragten im eigenen Haushalt den Abfall trennt und diejenigen, die es nicht tun, führen das Nichtbestehen der Infrastruktur für Abfalltrennung in ihrer Nähe als den Grund dafür.
\end{abstract}

Schlüsselwörter: Umweltbewußtsein, Wahrnehmung, Abfall, getrennte Abfallsammlung, Wiederverwertung 